UDC 621.18:621.039

V. Kravchenko, Dsc, Prof., Xiaolong Zhou

Odessa Polytechnic State University, 1 Shevchenko Ave., Odessa, Ukraine, 65044; e-mail: kravchenko@opu.ua

\title{
METHOD AND RESULTS OF HYDRAULIC CALCULATION OF THE HEAT EXCHANGE SURFACE OF THE ONCE-THROUGH STEAM GENERATOR
}

\begin{abstract}
В.П. Кравченко, Сяолун Чжоу. Методика та результати гідравлічного розрахунку теплообмінної поверхні прямоточного парогенератора. У світі росте інтерес до малих модульних реакторів, як перспективного джерела енергії. Україна 3 іiі розвиненим машинобудівним потенціалом може зайняти гідне місце у виробництві цих установок. Одним з основних елементів устаткування малих модульних реакторів $є$ парогенератор. Серед різних типів гідне місце займають прямоточні парогенератори. Прикладом малих модульних реакторів можуть служити транспортні ядерні енергетичні установки, наприклад КЛТ-40С. При проектуванні парогенератора проводиться розрахунок гідравлічного опору, що необхідно для вибору насосу і оптимізації конструктивних параметрів. У представленій статті розглядається методика гідравлічного розрахунку прямоточного парогенератора зі змієподібною поверхнею нагріву. В результаті аналізу літератури були відібрані формули для розрахунку гідравлічного опору для чотирьох режимів течії: поперечного обтікання теплоносієм горизонтальних змійовиків, руху усередині зігнутих труб однофазного робочого тіла, киплячої води і перегрітої пари. Приведені результати розрахунку парогенератора потужністю 45 МВт 3 різними конструктивними параметрами: діаметру змійовиків, горизонтального $\mathrm{i}$ вертикального кроків розташування змійовиків в пучку, швидкості живильної води і теплоносія. Отримані результати були верифіковані порівнянням 3 даними розрахунку за кодом ASPEN-TECH. В результаті дослідження було з'ясовано, що збільшення діаметру змійовиків, як і збільшення кроку розташування змійовиків в пучку не знижує гідравлічний опір, як очікувалося, а збільшує його в результаті погіршення теплообміну i, відповідно, збільшення теплообмінної поверхні. Збільшення швидкості теплоносія призводить до зростання опору по стороні теплоносія і не впливає на опір робочого тіла. Збільшення швидкості живильної води збільшує опір по стороні робочого тіла і не впливає на опір теплоносія.

Ключові слова: прямоточний парогенератор, гідравлічний опір, коефіцієнт опору тертя, оптимізація конструктивних
\end{abstract} параметрів

V. Kravchenko, Xiaolong Zhou. Method and results of hydraulic calculation of the heat exchange surface of the once-through steam generator. Ukraine with her developed machine-building potential can take the deserving place in the production of small modular reactors. One of basic elements of small modular reactors equipment is steam generator. Among different types a deserving place is occupied by once-through steam generator. small modular reactors can exemplify to transport nuclear installation, for example KLT-40S. The calculation of hydraulic resistance is included in designing of steam generators, that it is necessary for the choice of pumps and optimization of structural parameters. In the presented article methodology of hydraulic calculation of once-through steam generator is examined with the coiling surface of heating. As a result of analysis of literature formulas were selected for the calculation of hydraulic resistance for four modes of flow: transverse flow of the coolant over horizontal coils, movement in bent tubes of a single-phase working fluid, boiling water and superheated steam. Results over of calculation of steam generators are brought by power $45 \mathrm{MBT}$ with different structural parameters: diameter of coils, horizontal and vertical pitches of coils location in a bunch, speed of feedwater and coolant. The got results were verified by comparing to data of calculation on the code of ASPEN-TECH. It was found out as a result of research that increase of diameter of coils, as well as the increase of pitches of coils location in a bunch does not reduce hydraulic resistances, as expected, but increases them as a result of worsening of heat exchange and, accordingly, increase of heat-exchange surface. The increase of speed of coolant results in the height of resistance on the side of coolant and does not influence on resistance of working body. The increase of speed of feedwater increases resistance on the side of working fluid and does not influence on resistance of coolant.

Keywords: once-through steam generator, hydraulic resistance, coefficient of resistance of friction, optimization of structural parameters

\section{Introduction}

In recent years, small modular reactors (SMR) have been attracting considerable attention around the world. Substantial progress has been made in many IAEA Member States in the development of SMRs as a potential option to enhance energy supply security in both developed and developing countries [1]. SMR designs incorporate innovative approaches to achieve simplicity, modularity and speed of build, as well as the passive safety features and proliferation resistance [2]. They have lower initial capital costs and are suitable for cogeneration and non-power generation applications such as provid-

DOI: 10.15276/opu.1.63.2021.07

(C) 2021 The Authors. This is an open access article under the CC BY license (http://creativecommons.org/licenses/by/4.0/). 
ing heat for industrial processes, hydrogen production or sea-water desalination [3]. The incremental capacity expansion associated with SMR deployment could provide a better match than the large-scale reactors to the limited grid capacity of many developing countries. Because of their lower capital requirements, SMRs could also effectively address the energy needs of small developing countries with limited financial resources [4].

Transport nuclear power plants (NPP), which have extensive operating experience and as a result of long-term monitoring have achieved high safety and reliability, can be considered as SMRs. First of all, such transport installations include the NPP of the KLT-40S type installed at a floating NPP [5].

Now there are a number of companies on the SMR market (Westinghouse, GE-Hitachi, NuScale, Advanced Reactor Concepts, L.L.C., Chinergy and Rosatom), and NuScale and Rosatom are the closest to the implementation of the project.

China National Nuclear Corporation announces development of LWR-based SMR due to enter service in 2025 [5-8].

According to the classification currently used by the IAEA, small reactors are the reactors with an equivalent electric power less than $300 \mathrm{MW}$, whose components and systems can be shop fabricated and then transported as modules to the sites for installation demand arises. Most of the SMR designs adopt advanced or even inherent safety features and are deployable either as a single or multimodule plant. SMRs are under development for all principal reactor lines: water cooled reactors, high temperature gas cooled reactors, liquid-metal, sodium and gas-cooled reactors with fast neutron spectrum, and molten salt reactors. The key driving forces of SMR development are fulfilling the need for flexible power generation for a wider range of users and applications, replacing ageing fossil-fired units, enhancing safety performance, and offering better economic affordability [9-11].

Though significant advancements have been made in various SMR technologies in recent years, some technical issues still attract considerable attention in the industry. These include for example control room staffing and human factor engineering for multi-module SMR plants, defining the source term for multimodule SMR plants with regards to determining the emergency planning zone, developing new codes and standards, and load-following operability aspects. Some potential advantages of SMRs like the elimination of public evacuation during an accident or a single operator for multiple modules are under discussion with regulators. Furthermore, although SMRs have lower upfront capital cost per unit, their generating cost of electricity will probably be substantially higher than that for large reactors [11].

Currently there are more than 70 SMR designs under development for different application. Two industrial demonstration SMRs are in advanced stage of construction: in Argentina (CAREM, an integral PWR), in People's Republic of China (HTR-PM, a high temperature gas cooled reactor). They are scheduled to start operation between 2021 and 2023 [11].

One of the few installations that already have operating experience is a transport nuclear power plant of the KLT-40s type [11]. This installation uses once-through steam generator (OTSG). This is a steam generator (SG) with a coil heating surface. The working fluid moves along the spiral coil from bottom to top. The coolant is located in the annular space, washing the coils from the outside, moving from top to bottom. This design is used on most PWR SMRs.

2. Analysis of the publication on the method of calculating hydraulic resistance and problem statement

The design of such a SG for promising NPPs involves the use of mathematical models and corresponding computer codes for thermal and hydraulic calculations. Despite the large amount of literature on heat transfer and hydraulic resistance of steam-generating channels, the corresponding calculation causes certain difficulties. Calculations based on different literature sources give different results. In [12] the method of thermal calculation is considered, which is consistent with the results of the computer code ASPEN-TECH. In [13], a method is considered for calculating the hydraulic resistance of SG sections before and after the heat exchange surface (HES). This article discusses the methodology for calculating the hydraulic resistance of the HES. 
The hydraulic system of a NPP consists of coils, manifolds, core channels and blowers. Additional devices included in the hydraulic system are heat exchangers, fittings, throttling and separating devices. A closed hydraulic system of inlet and outlet coils, distribution devices inside the reactor vessel and channels (cassettes) with fuel elements is called a circulation loop.

Most hydrodynamic calculations in nuclear power are related to channel flows. The main tasks in calculating such flows are to determine the hydraulic resistances of channels of various shapes and local resistances, to calculate the distribution of shear stresses. The purpose of calculating hydraulic resistance is to determine the pressure loss in the channels and the power consumption for pumping the coolant.

For hydraulic calculations, the following quantities characterizing the flow in the channels are used: the geometric characteristics of the channel (cross-sectional area, hydraulic diameter or other determining size, absolute equivalent roughness, etc.), velocity, and density of the medium. The average density of the medium is determined by the average temperature in the channel in this area. All coolants used in nuclear power, including liquid metals, are Newtonian liquids and, thus, obey general laws.

Hydrodynamic processes in SG HES are very diverse due to the properties and state of aggregation of moving substances, structural and geometric characteristics of channels, and flow structure.

The main determining factor is the structure of the flow, both single-phase and, to an even greater extent, two-phase. For single-phase flows, a method has been developed for calculating hydrodynamic processes based on the separation of flows into two types - with laminar and turbulent flow regimes. For these modes, there are approximate theoretical, and in most cases empirical, regularities that also take into account the properties of substances, structural and geometric features of the channels. For twophase flows, the mechanism of hydrodynamic processes becomes much more complicated, the possibilities of their theoretical analysis are significantly hampered, due to which, in comparison with singlephase flows, the role of empirical studies increases. The hydrodynamic processes of steam generators, equally with the processes of heat exchange, determine their perfection. The velocities of the coolants and the working fluid affect the technical and economic indicators and the reliability of the SG.

To determine the optimal speed, you need to know the hydraulic resistances arising in the channels of the HES. In most cases, hydraulic resistances are determined approximately, including for single-phase flows. In order to calculate the hydraulic resistance in the course of two-phase flows, knowledge of their volumetric and mass characteristics is required the difficulty of determining which is due to the presence of the phase slip velocity. These characteristics are also necessary for calculating the processes of separation of a steam-water mixture and drying of steam.

Due to the wide variety of SG design schemes, it may be necessary to calculate the hydraulic characteristics for various channel shapes such as tubes, bundles, tubes with longitudinal or transverse flow, etc. [14].

The calculation of hydraulic resistance is carried out to determine the total pressure drop in the heat exchanger and the power consumption for pumping heat transfer fluids.

When moving in the channels, the flow experiences a variety of influences, of which the most significant is friction caused by the viscosity of the medium. SG channels can have sections with different flow cross-sections, with a sharp transition from one cross-sectional size to another, sharp turns, blockage of flow cross-sections with details of fastening the HES, etc. In these sections of the channel, the flow experiences resistance to movement, called local resistance [14].

The sum of the friction resistances $\Delta p_{f}$ and local resistances $\Delta p_{l}$ called hydraulic resistance:

$$
\Delta p_{h}=\Delta p_{f}+\Delta p_{l} .
$$

For the steady-state mode of operation of the steam generator, the acceleration resistance during flow in a channel of constant cross-section is [14], Pa:

$$
\Delta p_{a}=w_{2}^{2} \rho_{2}-w_{1}^{2} \rho_{1}
$$


where $w_{2}$ and $w_{1}$ - respectively, the flow rate at the exit from the section and the entrance to it, $\mathrm{m} / \mathrm{s}$; $\rho_{2}$ and $\rho_{1}-$ flux density at the outlet and inlet, respectively, $\mathrm{kg} / \mathrm{m}^{3}$.

In the channels, during vertical movement, resistance arises due to the rise of the mass to a certain height. This resistance is called gravity resistance $\Delta p_{g}$. It depends on the density of the medium and the difference in heights (geodetic) of the beginning and end of the considered section of the channel. With a downward movement, this value will no longer be resistance, but on the contrary, it will be spent on overcoming resistance [14].

Gravity resistance $\Delta p_{g}, \mathrm{~Pa}$, defined as:

$$
\Delta p_{g}=\rho \cdot g \cdot H,
$$

where $g$ - acceleration of gravity, $\mathrm{m} / \mathrm{s}^{2} ; H$ - section height, $(H=l \cdot \sin \gamma) ; \quad l$ - channel length, $\mathrm{m} ; \gamma-$ channel slope, grad; $\rho$ - medium density, $\mathrm{kg} / \mathrm{m}^{3}$.

The total resistance to flow is defined as:

$$
\Delta p_{r}=\Delta p_{h} \pm \Delta p_{a} \pm \Delta p_{g} .
$$

The sign of the second term on the right in expression (4) depends on whether the flow is accelerated or slowed down when the density of the coolant changes. When the density decreases (the flow is accelerated), the "+" sign is selected, while the density increases (the flow slows down), the "-" sign. The gravity resistance has a "-" sign if the directions of forced and natural convection coincide, a "+" sign if they are opposite [11].

As will be shown below, there are several methods to calculate the hydraulic resistance and hence have problems selecting specific shape.

The aim of the work is to develop a method for calculating the hydraulic resistance of a HES.

3. Methods for the hydraulic resistance calculating during the flow of the coolant and the working fluid

3.1. Methods for the hydraulic resistance calculating for a transverse flow of a coolant around a bundle of coils.

The resistance of transversely streamlined tube bundles is complex and includes frictional resistance, inlet and outlet losses. This resistance is calculated as a whole and is considered a special type of resistance [17]. The initial parameters required for all calculations are shown in Table 1.

Cross-sectional area between tubes:

$$
F_{b . t}=F_{\text {shell }}-F_{p}=\frac{\pi}{4}\left(D_{\text {shell }}^{2}-D_{c}^{2}\right)-\pi \cdot D_{\text {av }} \cdot d_{\text {t.out }} \cdot n_{w}=0.106 \mathrm{~m}^{2} .
$$

Average speed:

$$
\omega_{c o}^{a v}=\frac{G_{c o} \cdot V_{c o}^{a v}}{F_{b . t}}=3.917 \frac{\mathrm{m}}{\mathrm{s}} .
$$

The number of rows in the bundle of the direction of flow of the coolant:

$$
Z=\frac{H_{\mathrm{HET}}}{S_{2}}+1=\frac{3.478}{0.024}+1=146 \text {. }
$$

Reynolds number:

$$
\operatorname{Re}=\frac{\omega_{t n}^{s r} \cdot d_{t r, n a r}}{v_{t n}^{s r}}=688751.53
$$


Initial data for calculating OTSG $[12,13]$

\begin{tabular}{l|c|c}
\hline \multicolumn{1}{c|}{ Parameter } & Units & Value \\
\hline Power of SG & $\mathrm{MW}$ & 45 \\
\hline Coolant flow $G_{c o}$ & $\mathrm{~kg} / \mathrm{s}$ & 314.24 \\
\hline Steam mass flow & $\mathrm{kg} / \mathrm{s}$ & 16.98 \\
\hline Coolant pressure at the OTSG inlet & $\mathrm{MW}$ & 15 \\
\hline Coolant temperature at OTSG inlet & ${ }^{\circ} \mathrm{C}$ & 297.8 \\
\hline Coolant temperature at OTSG outlet & ${ }^{\circ} \mathrm{C}$ & 270 \\
\hline Feed water (FW) pressure at OTSG outlet & $\mathrm{MW}$ & 3.7 \\
\hline FW temperature at OTSG inlet & ${ }^{\circ} \mathrm{C}$ & 65 \\
\hline FW temperature at OTSG outlet & ${ }^{\circ} \mathrm{C}$ & 275 \\
\hline Outer diameter of tube, $d_{t . o u t}$ & $\mathrm{~m}$ & 0.022 \\
\hline Tube wall thickness & $\mathrm{m}$ & 0.0028 \\
\hline Distance between coil layers, $s_{1}$ & $\mathrm{~m}$ & 0.024 \\
\hline Distance between tubes in the layer, $s_{2}$ & $\mathrm{~m}$ & 0.024 \\
\hline Number of tubes & - & 143 \\
\hline Number of coil layers, $n_{w}$ & - & 22 \\
\hline FW input speed & $\mathrm{m} / \mathrm{s}$ & 0.57 \\
\hline HES height, $H_{\text {HES }}$ & $\mathrm{m}$ & 3.478 \\
\hline Center tube diameter, $D_{c}$ & $\mathrm{~m}$ & 0.25 \\
\hline Outer diameter of the flow path $D_{\text {shell }}$ & $\mathrm{m} / \mathrm{m}{ }^{3}$ & 7.305 \\
\hline Average diameter of coils $D_{a v}$ & & 0.77756 \\
\hline Average density of the coolant, $\rho_{c}^{a v}$ & $\mathrm{~m}$ & 755.126 \\
\hline
\end{tabular}

Acceleration resistance of coolant:

$$
\begin{gathered}
\Delta p_{a}=w_{2}^{2} \cdot \rho_{2}-w_{1}^{2} \cdot \rho_{1}=3.787^{2} \cdot 780.17-4^{2} \cdot 730.07= \\
=-767.858 \mathrm{~Pa}=-0.00768 \text { bar. }
\end{gathered}
$$

Gravity resistance of coolant:

$$
\begin{aligned}
\Delta p_{g} & =\rho_{c o}^{a v} \cdot g \cdot H_{\text {HЕT }}=755.126 \cdot 9.8 \cdot 3.478= \\
& =25740.02 \mathrm{~Pa}=0.257 \text { bar. }
\end{aligned}
$$

Let us estimate the values of the resistance coefficient during the transverse flow of smooth tube chess and corridor beams according to $[16,17]$.

The hydraulic resistance of a multi-row bundle with a chess and corridor arrangement of smooth tubes is determined by the dependence:

$$
\Delta p_{f}=\xi \cdot Z \cdot \frac{\rho \omega^{2}}{2},
$$

where $\omega$ - speed at the smallest flow area, $\mathrm{m} / \mathrm{s} ; \xi$ - coefficients of hydraulic resistance of one row.

The coefficients of hydraulic resistance $\xi$ of one row for a chess and corridor arrangement of tubes are determined from nomograms depending on $\operatorname{Re}=688751$ and $\sigma_{1}=\frac{s_{1}}{d}=\sigma_{2}=\frac{s_{2}}{d}=1.09$ (Fig. 1) [17]. It should be noted that the nomograms in [16] have errors in designations that makes it impossible to apply them. 

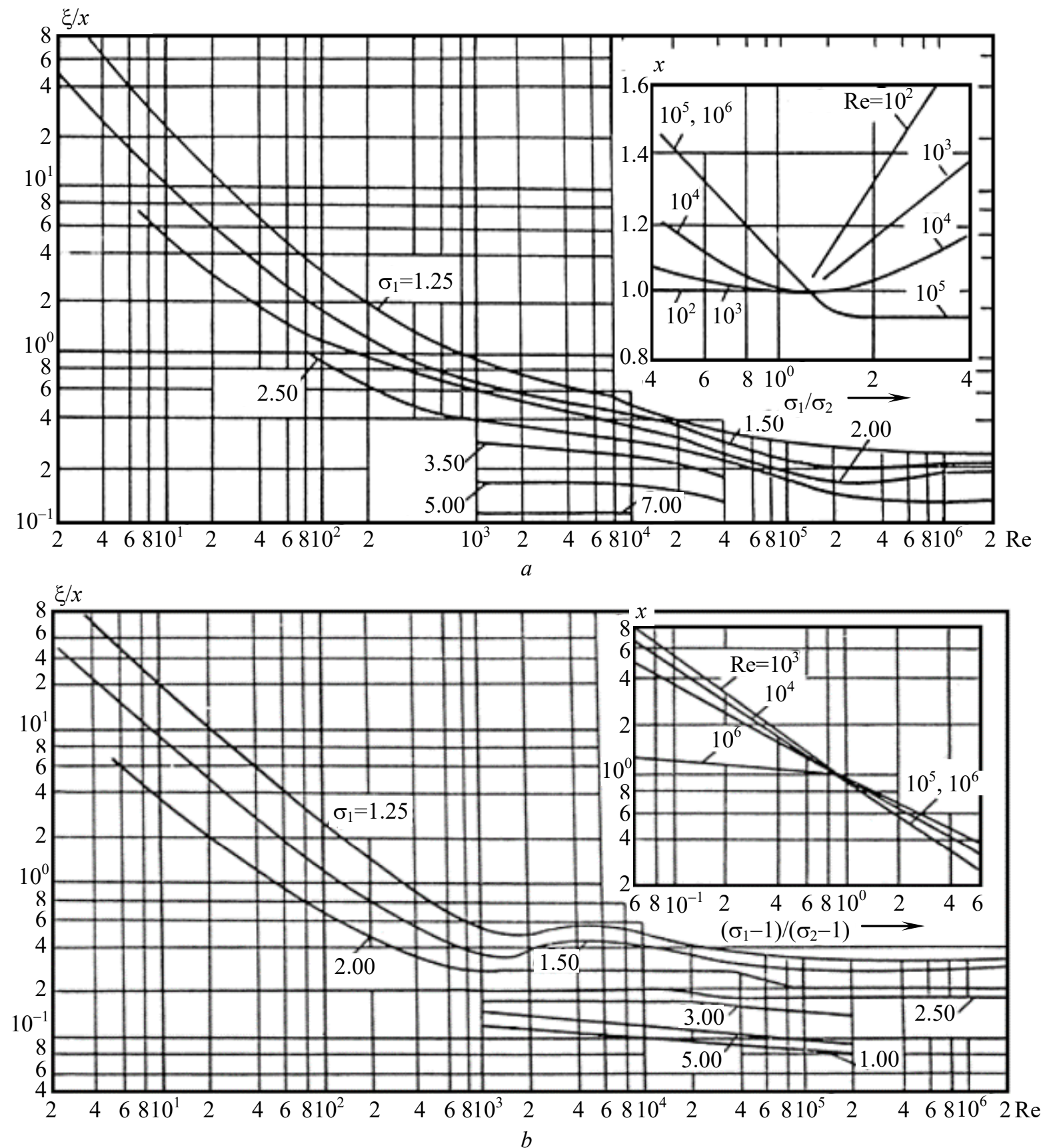

Fig. 1. Nomograms for determining the coefficient of resistance during the transverse flow of the chess $(a)$ and corridor $(b)$ tube bundle

Chess arrangement of tubes:

$$
\begin{gathered}
\xi_{\text {ch.a }}=\left(\frac{\xi}{x}\right) \cdot x=10^{-0.7} \cdot 1.1=0.219, \\
\Delta p_{\text {f.ch.a }}=0.219 \cdot 146 \cdot \frac{755.126 \cdot 3.917^{2}}{2}=185222 \mathrm{~Pa}=1.85 \mathrm{bar} .
\end{gathered}
$$

Corridor arrangement of tubes: 


$$
\begin{gathered}
\xi_{c o . a}=10^{-0.64} \cdot 10^{-0.1}=0.18 \\
\Delta p_{\text {f.co.a }}=0.18 \cdot 146 \cdot \frac{755.126 \cdot 3.917^{2}}{2}=152237.6 \mathrm{~Pa}=1.52 \mathrm{bar} .
\end{gathered}
$$

Comparison of the obtained results indicates their closeness, which is plausible. With a checkerboard flow, the resistance is slightly higher than with a corridor flow, which confirms the well-known fact.

In [16], when flowing around a beam $Z$ of successive rows, in addition to nomograms, a formula is proposed for the beam resistance coefficient:

$$
\xi=\xi_{1} Z,
$$

where $Z$ - number of rows of tubes; $\xi_{1}$ - resistance coefficient of one row.

In what follows, we are talking about the definition of $\xi_{0}$, that this is not explained. One can guess that by $\xi_{0}$ we mean $\xi_{1}$.

According to [16]:

$$
\begin{gathered}
x_{1}=\frac{s_{1}}{d}=1.09 ; \quad x_{2}=\frac{s_{2}}{d}=1.09, \\
\psi=\frac{\left(x_{1}-1\right)}{\left(x_{2}-1\right)}=1 .
\end{gathered}
$$

For corridor arrangement of tubes:

$$
\begin{gathered}
\xi_{0}=2\left(x_{1}-1\right)^{-0.5} \mathrm{Re}^{-0.2}=0.45, \\
\Delta p_{f}=\xi_{1} Z \frac{\rho \omega^{2}}{2}=3.8 \text { bar } .
\end{gathered}
$$

For chess arrangement of tubes:

$$
\xi=\xi_{0}(Z+1)
$$

where $\xi_{0}=C \mathrm{Re}^{-0.27}$.

For $\psi=1$ and $x_{1}=1$, the following formula for $C$ is proposed:

$$
\begin{gathered}
C=3.2+0.66(1.7-\psi)^{1.5}+\frac{1.44-x_{1}}{0.11}\left[0.8+0.2(1.7-\psi)^{1.5}\right]= \\
=3.2+0.66(1.7-1)^{1.5}+\frac{1.44-1.09}{0.11}\left[0.8+0.2(1.7-1)^{1.5}\right]=6.504 .
\end{gathered}
$$

Then:

$$
\begin{gathered}
\xi_{0}=C \cdot \operatorname{Re}^{-0.27}=6.504 \cdot(688751)^{-0.27}=0.173, \\
\xi=\xi_{0} \cdot(Z+1)=0.173 \cdot(146+1)=25.36, \\
\Delta p_{f}=25.36 \cdot \frac{3.917^{2}}{2} \cdot 755.126=146932.39 \mathrm{~Pa}=1.469 \mathrm{bar} .
\end{gathered}
$$

Comparison of the results shows doubtfulness of the correctness of the calculation methodology for the corridor location. For chess location, the result is close to the data obtained using Fig. 1. and can be considered correct.

Let us carry out the calculation for a transverse flow by the method [18, 19]. Coils with an inclination of about $85^{\circ}$ from the vertical direction can be considered horizontal. If the flow washes the tube bundle with an angle of attack $\psi$ different from $90^{\circ}$, then in (25) it is necessary to introduce a correction from Table 2. 
Allowance for the angle of attack for transverse flow

\begin{tabular}{c|c|c|c|c|c|c|c}
\hline$\psi$ & $90^{\circ}$ & $80^{\circ}$ & $70^{\circ}$ & $60^{\circ}$ & $50^{\circ}$ & $40^{\circ}$ & $30^{\circ}$ \\
\hline$\varepsilon_{\psi}$ & 1 & 1 & 0.95 & 0.83 & 0.69 & 0.53 & 0.38 \\
\hline
\end{tabular}

In the case of transverse flushing of tube bundles, the flow resistance is based on alternating narrowing and expansion of the flow area. The frictional resistance is negligible compared to the sum of these local resistances. Therefore, in technical calculations, the friction resistance is not separately determined, but the total hydraulic resistance of the tube bundle is immediately calculated $\Delta p_{r . b}, \mathrm{~Pa}$ :

$$
\Delta p_{r . b}=\xi_{b} \cdot \rho \cdot\left(\frac{w^{2}}{2}\right) .
$$

The drag coefficient of the transverse tube bundles $\xi_{b}$ depends on the design characteristics of the tube bundles and the flow regime. The following relations can be used with a sufficient degree of accuracy to determine $\xi_{b}$ :

For chess arrangement of tubes:

$$
\begin{aligned}
& - \text { at } \frac{s_{1}}{d_{\text {t.out }}}<\frac{s_{2}}{d_{\text {t.out }}} \\
& \xi_{b}=(4+6.6 Z) \operatorname{Re}^{-0.28}=(4+6.6 \cdot 146) \cdot 688751.53^{-0.28}=22.44 ; \\
& - \text { at } \frac{s_{1}}{d_{t . o u t}}>\frac{s_{2}}{d_{t . \text { out }}} \\
& \xi_{b}=(5.4+3.4 Z) \operatorname{Re}^{-0.28}=(5.4+3.4 \cdot 146) 688751.53^{-0.28}=11.64 .
\end{aligned}
$$

For corridor arrangement of tubes:

$$
\begin{gathered}
\xi_{b}=(6+9 Z) \operatorname{Re}^{-0.26}\left(\frac{s_{1}}{d_{\text {t.out }}}\right)^{-0.23}= \\
=(6+9 \cdot 146) 688751.53^{-0.26}\left(\frac{0.02398}{0.022}\right)^{-0.23}=30.01 .
\end{gathered}
$$

It is assumed that the resistance of the corridor and chess bundles can't differ 2 times. Therefore, the result for corridor bundles is considered doubtful.

Since the condition $\frac{s_{1}}{d_{H}}=\frac{s_{2}}{d_{H}}$ is absent in the condition for choosing a formula for a chess bundle, then it is customary to use the average value between the obtained from formulas (27) and (28).

$$
\begin{gathered}
\xi=\frac{22.44+11.64}{2}=17.04, \\
\Delta p_{f}=17.04 \cdot \frac{3.917^{2}}{2} \cdot 755.126=0.987 \mathrm{bar} .
\end{gathered}
$$

The total resistance of the downward cooling flow is defined as:

$$
\Delta p_{r}=\Delta p_{f}-\Delta p_{g}+\Delta p_{a}=0.987-0.257+(-0.00768)=0.724 \text { bar . }
$$

Comparison of the results obtained using the methodology $[16,17]$ with the results according to $[18,19]$ shows that they differ by two times. As a result of calculations based on the same initial data using the ASPEN-TECH computer code, a resistance to the coolant of 0.73 bar was obtained. Thus, we can conclude that the technique $[16,17]$ is not suitable for the required conditions. The closest to the standard result is given by the method $[18,19]$. 
3.2. Methods for the hydraulic resistance calculating when the working fluid flows in a tube

The steam-generating channel, in which the working fluid (WF) moves from bottom to top, is divided into three sections: economizer (EC), evaporative (EV), and super heater (SU). Different formulas are used to calculate each section. The total resistance of the channel is determined as the sum of the resistances of the three sections. Some calculation results are shown in Table 3.

Table 3

Initial data from thermal calculation [10]

\begin{tabular}{|c|c|c|c|c|}
\hline Sections & \multicolumn{2}{|c|}{ Parameter } & Units & Value \\
\hline & \multicolumn{2}{|l|}{ Roughness, $\Delta$} & $\mathrm{m}$ & 0.00001 \\
\hline & \multicolumn{2}{|c|}{ Inner diameter of heat exchange tube (HET), $d_{t, i n}$} & $\mathrm{~m}$ & 0.0164 \\
\hline & \multicolumn{2}{|c|}{ Passage area WF, $F_{\mathrm{WF}}$} & $\mathrm{m}^{2}$ & 0.03019 \\
\hline & \multicolumn{2}{|c|}{ Average density WF, $\rho_{\mathrm{wF}}^{a v}$} & $\mathrm{~kg} / \mathrm{m}^{3}$ & 497.7 \\
\hline \multirow{5}{*}{$\mathrm{EC}$} & \multicolumn{2}{|l|}{ Height of HES, $H_{\mathrm{EC}}$} & $\mathrm{m}$ & 0.4967 \\
\hline & \multicolumn{2}{|l|}{ Length of HET, $l_{\mathrm{EC}}$} & $\mathrm{m}$ & 5.9635 \\
\hline & \multicolumn{2}{|c|}{ Average density WF, $\rho_{\text {WF.EC }}^{a v}$} & $\mathrm{~kg} / \mathrm{m}^{3}$ & 890.377 \\
\hline & \multicolumn{2}{|c|}{ Reynolds number, $\operatorname{Re}_{\text {WF.EC }}^{a v}$} & - & 53044.95 \\
\hline & \multicolumn{2}{|c|}{ Average speed, $\omega_{\mathrm{WF} . \mathrm{EC}}^{a v}$} & $\mathrm{~m} / \mathrm{s}$ & 0.6167 \\
\hline & \multicolumn{2}{|c|}{ Height of HES, $H_{\mathrm{EV}}$} & $\mathrm{m}$ & 2.668 \\
\hline & \multicolumn{2}{|l|}{ Length of HET, $l_{\mathrm{EV}}$} & $\mathrm{m}$ & 32.034 \\
\hline & \multicolumn{2}{|c|}{ Reynolds number, $\operatorname{Re}_{\text {wF.Ev }}^{a v}$} & - & 87002 \\
\hline EV & \multicolumn{2}{|c|}{ Input speed, $\omega_{\mathrm{WF} .0}^{\mathrm{EV}}$} & $\mathrm{m} / \mathrm{s}$ & 0.704 \\
\hline LV & \multicolumn{2}{|l|}{$\rho^{\prime}$} & $\mathrm{kg} / \mathrm{m}^{3}$ & 837.11 \\
\hline & \multicolumn{2}{|l|}{$\rho^{\prime \prime}$} & $\mathrm{kg} / \mathrm{m}^{3}$ & 18.836 \\
\hline & \multicolumn{2}{|l|}{$\rho_{\mathrm{WFEV}}^{a v}$} & $\mathrm{~kg} / \mathrm{m}^{3}$ & 408.66 \\
\hline & \multicolumn{2}{|l|}{$\rho \omega$} & $\mathrm{kg} /\left(\mathrm{m}^{2} \mathrm{~s}\right)$ & 562.268 \\
\hline \multirow{6}{*}{ SU } & \multicolumn{2}{|l|}{ Height of HES, $H_{\mathrm{su}}$} & $m$ & 0.3135 \\
\hline & \multicolumn{2}{|l|}{ Length of HET, $l_{\mathrm{su}}$} & $m$ & 3.763 \\
\hline & \multicolumn{2}{|c|}{ Average density WF, $\rho_{\mathrm{WF} . \mathrm{aU}}^{a v}$} & $\mathrm{~kg} / \mathrm{m}^{3}$ & 15.987 \\
\hline & \multicolumn{2}{|c|}{ Reynolds number, $\mathrm{Re}_{\mathrm{WF.SU}}^{a v}$} & - & 510473.0 \\
\hline & \multicolumn{2}{|c|}{ Average speed, $\omega_{\mathrm{WF} . \mathrm{Su}}^{a v}$} & $\mathrm{~m} / \mathrm{s}$ & 31.803 \\
\hline & \multicolumn{2}{|c|}{ At the entrance } & \multicolumn{2}{|c|}{ At the exit } \\
\hline \multirow{2}{*}{$\mathrm{EC}$} & $\rho_{\mathrm{WF.EC}}^{\prime}$ & 982.26 & $\rho_{\mathrm{WF} . \mathrm{FC}}^{\prime \prime}$ & 798.49 \\
\hline & $\omega_{\mathrm{WF} . \mathrm{EC}}^{\prime}$ & 0.5724 & $\omega_{\mathrm{WF} . \mathrm{EC}}^{\prime \prime}$ & 0.704 \\
\hline \multirow{2}{*}{ EV } & $\rho_{\mathrm{WF.EV}}^{\prime}$ & 798.49 & $\rho_{\mathrm{WFEV}}^{\prime \prime}$ & 18.836 \\
\hline & $\omega_{\text {WF.EV }}^{\prime}$ & 0.704 & $\omega_{\mathrm{WF} . \mathrm{EV}}^{\prime \prime}$ & 29.851 \\
\hline \multirow{2}{*}{ SU } & $\rho_{\mathrm{WF} . \mathrm{SU}}^{e n}$ & 18.836 & $\rho_{\mathrm{WFFSU}}^{\text {exit }}$ & 13.138 \\
\hline & $\omega_{\mathrm{WF} . S U}^{e n}$ & 29.851 & $\omega_{\mathrm{WF} . \mathrm{SU}}^{\text {exit }}$ & 42.798 \\
\hline
\end{tabular}

a) Economizer section [13, 14].

For all turbulent flow regimes of a single-phase medium, the friction coefficient is determined by the formula [11]:

$$
\xi_{0}=\frac{1}{(1.82 \lg \mathrm{Re}-1.64)^{2}}=\frac{1}{(1.82 \lg 53044.95-1.64)^{2}}=0.0206 .
$$

Coils. The coefficient of frictional drag for single-phase flow in coils is determined by the formula: 


$$
\xi_{f . \mathrm{EC}}=\xi_{0} \cdot\left[\operatorname{Re}_{\mathrm{WF} . \mathrm{EC}}^{a v} \cdot\left(\frac{d_{t . i n}}{D_{a v}}\right)\right]^{0.05}=0.0206 \cdot\left[53044.95\left(\frac{0.0164}{0.77756}\right)^{2}\right]^{0.05}=0.024,
$$

where $\xi_{0}$ - resistance coefficient for a straight tube with the same roughness; $d_{t . i n}-$ inner diameter of HET, m; $D_{a v}$ - average diameter of coils, $\mathrm{m}$.

The frictional resistance is calculated by the formula:

$$
\begin{gathered}
\Delta p_{f . \mathrm{EC}}=\xi_{f . \mathrm{EC}} \cdot\left(\frac{l_{\mathrm{EC}}}{d_{t . i n}}\right) \cdot \rho_{\mathrm{WF} . \mathrm{EC}}^{a v} \cdot\left(\frac{\omega_{\mathrm{WF} . \mathrm{EC}}^{a v}}{2}\right)= \\
=0.024 \cdot\left(\frac{5.9635}{0.0164}\right) \cdot 890.377 \cdot\left(\frac{0.6167^{2}}{2}\right)=1489.035 \mathrm{~Pa}=0.0149 \text { bar. }
\end{gathered}
$$

The acceleration resistance of the economizer section is calculated according to (2) and is equal to:

$$
\Delta p_{a \text {.EC }}=74.076 \mathrm{~Pa}=0.00074 \text { bar. }
$$

The gravity resistance of the economizer section is calculated according to (3):

$$
\Delta p_{g . \mathrm{EC}}=\rho_{\mathrm{WF} . \mathrm{SU}}^{a v} \cdot g \cdot H_{\mathrm{EC}}=890.377 \cdot 9.8 \cdot 0.4967=4334.05 \mathrm{~Pa}=0.04334 \mathrm{bar} .
$$

b) Evaporation section $[16,17]$.

The flow regime of a two-phase medium depends on the velocity of the phases, the thermophysical parameters of the liquid and vapor, on the size and shape of the channel and its location in space.

Experience shows that there are basically four flow regimes such as bubble, slug, annular and emulsion.

Bubble mode is established at low vapor contents. With an increase in the vapor content, some bubbles merge into large formations that occupy most of the channel cross section and are separated by a relatively thin layer of liquid, in which small vapor bubbles may be located. As the vapor content further increases, the slug-like bubbles merge, forming a continuous vapor flow in the center of the channel, while the liquid phase moves along the walls. Part of the liquid in this mode moves in the form of drops in the vapor stream.

If you continue to increase the vapor content, then almost all of the liquid passes into the vapor flow and move in it in the form of drops evenly distributed throughout the volume. A rather thin liquid film remains on the surface of the channel, which can disappear completely when heated.

At pressures exceeding 3.5...4 MPa, the slug mode becomes unstable and the bubble mode immediately turns into an annular one.

Naturally, different flow regimes of a two-phase mixture should be taken into account when calculating hydraulic resistances [20].

The hydraulic resistance during a two-phase flow in tubes and channels of constant flow area is a function of a larger number of factors characterizing the dynamic properties and structure of a twophase flow (flow regime, phase slip, intensity of mass transfer between the near-wall zone and the flow core, etc.). Due to the great complexity of the hydrodynamics of two-phase systems, when developing design recommendations, simplified flow models are usually used, the main of which are homogeneous and stratified.

\section{Frictional resistance}

The coefficient of friction resistance during two-phase flow in helical coils is calculated by the following formulas [18]:

$$
\begin{gathered}
\xi_{0}=\frac{1}{(1.82 \lg \operatorname{Re}-1.64)^{2}}=\frac{1}{(1.82 \lg 87002.025-1.64)^{2}}=0.01851, \\
K_{f}=1+1.68\left(\frac{d}{D_{s r}}\right)^{0.65}=1+1.68\left(\frac{0.0164}{0.778}\right)^{0.65}=1.137,
\end{gathered}
$$




$$
\xi_{f . \mathrm{EV}}=\xi_{0} \cdot K_{f}=0.021
$$
formulas:

The hydraulic friction losses during a two-phase flow in helical coils are determined by different

- according to [16]:

$$
\Delta p_{f . \mathrm{EV}}=\xi_{f . \mathrm{EV}}\left(\frac{l}{d}\right) \frac{\omega^{\prime 2} \rho^{\prime}}{2}\left[1+x\left(\frac{\rho^{\prime}}{\rho^{\prime \prime}}-1\right)\right]
$$

- according to [17]:

$$
\Delta p_{f . \mathrm{EV}}=\xi_{f . \mathrm{EV}}\left(\frac{l}{d}\right) \frac{\omega^{\prime 2} \rho^{\prime}}{2}\left[1+\psi x\left(\frac{\rho^{\prime}}{\rho^{\prime \prime}}-1\right)\right],
$$

where $x$ - average for the considered section of the channel reduced mass steam content (as a rule, arithmetic averaging is used).

If the vapor content changes along the channel length from $x_{s}$ to $x_{f}$, then in the formula (42) substitute the average values of the steam content $\bar{x}$ and coefficient $\bar{\psi}$ :

$$
\psi=\frac{\psi_{f} x_{f}-\psi_{i} x_{i}}{x_{f}-x_{i}}
$$

where $\psi$ is determined using nomograms (Fig. 2.5 in [17] separately for unheated and heated tubes, as well as in Fig. 2.6). It turns out $\psi=1.45$.

The influence of the heat flux at two-phase flow in heated tubes on $\Delta p_{f}$ is taken into account by a correction factor [17]:

$$
\Delta p_{f . s u m}=\Delta p_{f}\left[1+4.4 \cdot 10^{-3}\left(\frac{q}{\rho \omega}\right)^{0.7}\right],
$$

where $\Delta p_{f}$ calculated by formulas (41) and (42);g-w/m²; $\rho \omega-\mathrm{kg} /\left(\mathrm{m}^{2} \cdot \mathrm{s}\right)$.

According to (42) and (44):

$$
\Delta p_{f . \mathrm{EV}}=303293.31 \mathrm{~Pa}=3.033 \text { bar. }
$$

By (41) and (44), the following results are obtained:

$$
\Delta p_{f . \mathrm{EV}}=212201.85 \mathrm{~Pa}=2.122 \text { bar. }
$$

Comparison of the results obtained using the methodology [14] and [16] shows that taking into account the coefficient $\psi$ according to [16] leads to an overestimation of the result. Therefore, we choose a method for calculating the hydraulic resistance in the evaporating section according to [14] using formulas (41) and (44).

\section{Acceleration resistance}

According to [16]:

$$
\begin{gathered}
\Delta p_{a}=\frac{(\rho \cdot \omega)^{2}}{\rho_{\mathrm{WFEVV}}^{\prime}} \cdot\left(\frac{\rho_{\mathrm{WFEV}}^{\prime \prime}}{\rho_{\mathrm{WFEV}}^{\prime}}-1\right) \cdot\left(x_{f}-x_{i}\right)=\frac{(562 \cdot 268)^{2}}{837.11} \cdot\left(\frac{18.836}{837.11}-1\right) \cdot(1-0)= \\
=16395.86 \mathrm{~Pa}=0.164 \mathrm{bar} ;
\end{gathered}
$$

- according to [14] and [18]:

$$
\Delta p_{a}=w_{\text {exit }}^{2} \rho_{\text {exit }}-w_{\text {en }}^{2} \rho_{e n}=16395.86 \mathrm{~Pa}=0.164 \text { bar; }
$$

- according to [17]: 


$$
\begin{gathered}
\Delta p_{a}=\rho_{\text {exit }}^{\prime}\left(w_{0}^{\text {exit }}\right)^{2}\left[1+x_{f}\left(\frac{\rho_{\text {exit }}^{\prime}}{\rho_{\text {exit }}^{\prime \prime}}-1\right)\right]-\rho_{e n}^{\prime}\left(w_{0}^{e n}\right)^{2}\left[1+x_{i}\left(\frac{\rho_{e n}^{\prime}}{\rho_{e n}^{\prime \prime}}-1\right)\right]= \\
=16395.86 \mathrm{~Pa}=0.164 \mathrm{bar},
\end{gathered}
$$

where $x_{f}, x_{i}$ - final and initial steam quality; $\rho \omega=\rho_{\mathrm{WFEV}}^{\prime} \omega_{\mathrm{WFEV}}^{\prime}=\rho_{\mathrm{WFEV}}^{\prime \prime} \omega_{\mathrm{WFEV}}^{\prime \prime}=$ const .

As you can see, the results obtained from all sources are the same. Any formula can be used; however, for simplicity, it is preferable (48).

The gravity resistance of the evaporating section is calculated according to (3):

$$
\Delta p_{g . \mathrm{EV}}=\rho_{\mathrm{WFEV}}^{a v} \cdot g \cdot H_{\mathrm{EV}}=408.66 \cdot 9.8 \cdot 2.668=10680.65 \mathrm{~Pa}=0.1068 \text { bar. }
$$

c) Superheating section.

The hydraulic resistance of the superheating section is calculated according to (33), (34), (35):

$$
\xi_{f . \mathrm{Su}}=0.017,
$$

$$
\Delta p_{f . \mathrm{Su}}=31665.899 \mathrm{~Pa}=0.3166 \text { bar. }
$$

The acceleration resistance of the superheating section is calculated according to (2):

$$
\Delta p_{\text {a.SU }}=7271.999 \mathrm{~Pa}=0.0727 \text { bar. }
$$

The gravity resistance of the superheating section is calculated according to (3):

$$
\Delta p_{g . \mathrm{SU}}=\rho_{\mathrm{WF} . \mathrm{SU}}^{a v} \cdot g \cdot H_{\mathrm{SU}}=15.987 \cdot 9.8 \cdot 0.3135=49.061 \mathrm{~Pa}=0.000491 \mathrm{bar} .
$$

Full resistance to movement of the working fluid:

$$
\begin{gathered}
\Delta p_{\mathrm{WF}}=\Delta p_{f . \mathrm{EC}}+\Delta p_{f . \mathrm{EV}}+\Delta p_{f . \mathrm{SU}}+\Delta p_{a . \mathrm{EC}}+\Delta p_{a . \mathrm{EV}}+\Delta p_{a . \mathrm{SU}}+\Delta p_{g . \mathrm{EC}}+\Delta p_{g . \mathrm{EV}}+\Delta p_{g . \mathrm{SU}}= \\
=284162.493 \mathrm{~Pa}=2.84 \text { bar. }
\end{gathered}
$$

\begin{tabular}{|c|c|c|c|c|c|}
\hline & & \multicolumn{2}{|c|}{ Working fluid } & \multicolumn{2}{|c|}{ Coolant } \\
\hline & & Value, bar & $\%$ & Value, bar & $\%$ \\
\hline \multirow{4}{*}{$\mathrm{EC}$} & $\Delta p_{f . \mathrm{EC}}$ & 0.01489 & & 0.14273 & \\
\hline & $\Delta p_{a . \mathrm{EC}}$ & 0.00074 & & -0.00213 & \\
\hline & $\Delta p_{\text {g.EC }}$ & 0.04334 & & 0.03750 & \\
\hline & $\Delta p_{\mathrm{EC}}$ & 0.05897 & 2.0 & 0.1031 & 14.24 \\
\hline \multirow{4}{*}{ EV } & $\Delta p_{f . \mathrm{EV}}$ & 2.12202 & & 0.74792 & \\
\hline & $\Delta p_{a . \mathrm{EV}}$ & 0.16396 & & -0.00514 & \\
\hline & $\Delta p_{g . \mathrm{EV}}$ & 0.10681 & & 0.19444 & \\
\hline & $\Delta p_{\mathrm{EV}}$ & 2.393 & 84.3 & 0.5486 & 75.74 \\
\hline \multirow{5}{*}{ SU } & $\Delta p_{f . \mathrm{SU}}$ & 0.31666 & & 0.09546 & \\
\hline & $\Delta p_{a . \mathrm{SU}}$ & 0.07272 & & -0.00042 & \\
\hline & $\Delta p_{g . \mathrm{SU}}$ & 0.00049 & & 0.02245 & \\
\hline & $\Delta p_{\mathrm{SU}}$ & 0.39 & 13.7 & 0.0726 & 10.02 \\
\hline & $\Delta p_{\text {sum }}$ & 2.84 & 100 & 0.7243 & 100 \\
\hline
\end{tabular}

\section{Calculation results}

The main results of calculating a once-through steam generator with a coil HES according to the initial data in Table 1 are given in Table 4.

Table 4

Calculation results 
Thus, the evaporative section makes the maximum contribution to the total resistance. Of the components of total resistance, frictional resistance is of greatest importance.

Let us consider the influence of the main design parameters on the hydraulic resistance of the steam generator in terms of the coolant and the working fluid. Table 5 shows the calculation results of the hydraulic resistance on both sides, depending on the diameter of the HETs. The rest of the parameters are kept the same as in the previous calculation.

Table 5

Effect of changing the diameter of the HET on the hydraulic resistance of the steam generator

\begin{tabular}{c|c|c|c|c|c}
\hline$d_{\text {t.out }}, \mathrm{mm}$ & 16 & 18 & 20 & 22 & 24 \\
\hline$\delta_{\text {wall }}, \mathrm{m}$ & 0.002 & 0.0022 & 0.0025 & 0.0028 & 0.0028 \\
\hline$D_{\text {shell }}, \mathrm{m}$ & 1.2789 & 1.2898 & 1.2746 & 1.3051 & 1.270 \\
\hline$F, \mathrm{~m}^{2}$ & 275.29 & 299.98 & 329.92 & 360.07 & 367.4 \\
\hline$h_{\text {height }}, \mathrm{m}$ & 1.9324 & 2.0142 & 2.680 & 3.4769 & 4.3596 \\
\hline$n_{t}$ & 268 & 208 & 171 & 143 & 114 \\
\hline$n_{w}$ & 30 & 27 & 24 & 22 & 20 \\
\hline$\omega_{\mathrm{CO}}^{e n}, \mathrm{M} / \mathrm{s}$ & 4.1038 & 4.0191 & 4.1038 & 4.047 & 4.104 \\
\hline$\omega_{w F}^{e n}, \mathrm{M} / \mathrm{s}$ & 0.5705 & 0.5723 & 0.5722 & 0.572 & 0.5704 \\
\hline$\Delta P_{\mathrm{wF}}$, bar & 2.2699 & 2.4412 & 2.6377 & 2.84 & 2.925 \\
\hline$\Delta P_{\mathrm{wF}}^{\mathrm{EC}}$, bar & 0.0383 & 0.0396 & 0.0486 & 0.05897 & 0.0692 \\
\hline$\Delta P_{\mathrm{wF}}^{\mathrm{EV}}$, bar & 1.8808 & 2.037 & 2.2116 & 2.393 & 2.462 \\
\hline$\Delta P_{\mathrm{wF}}^{\mathrm{SU}}$, bar & 0.3507 & 0.3644 & 0.3765 & 0.39 & 0.393 \\
\hline$\Delta P_{\mathrm{CO}}$, bar & 0.6986 & 0.5801 & 0.6783 & 0.7243 & 0.8035 \\
\hline$\Delta P_{\mathrm{CO}}^{\mathrm{EC}}$, bar & 0.1057 & 0.086 & 0.0984 & 0.1031 & 0.1121 \\
\hline$\Delta P_{\mathrm{CO}}^{\mathrm{EV}}$, bar & 0.5121 & 0.4295 & 0.5085 & 0.5486 & 0.6125 \\
\hline$\Delta P_{\mathrm{CO}}^{\mathrm{SU}}$, bar & 0.0807 & 0.0646 & 0.0713 & 0.0726 & 0.0792 \\
\hline
\end{tabular}

An analysis of the results presented showed that with an increase in the HET diameter, the hydraulic resistance of the working fluid increases, which is determined by an increase in the HET length. The latter is explained by the deterioration of heat transfer with an increase in the tube diameter. In this case, the coolant resistance changes insignificantly. The fluctuation in the value of $\Delta P_{\text {Со }}$ is explained by fluctuations in the coolant velocity, which is refined with the calculated value of the coil layers.

Figure 2 shows the dependence of the hydraulic resistance on the coolant speed. As can be seen from the calculation results, the hydraulic resistance of the working fluid does not change in this case. The resistance of the coolant increases with increasing speed of the coolant. Increasing the speed by 2 times leads to an increase in resistance by 10 times.

Figure 3 shows the influence of the feed water velocity on the hydraulic resistance of the HES. In this case, the resistance of the coolant does not change. The resistance of the working fluid increases by a factor of 7.5 with an increase in the feed water velocity by 2 times. With the same length of tubes, the resistance would increase by 4 times. However, this also increases the length of the tubes, which leads to an additional increase in the resistance of the working fluid.

Figure 4 shows the change in the hydraulic resistance of the HES with an increase in the relative pitch the coils along the vertical. At the same time, as you can see, the resistance on both sides practically does not change. 
Figure 5 pitch between the layers of coils on the hydraulic resistance of the SG, it leads to an increase in resistance both in the coolant and the working medium. This is due to deterioration in heat transfer and, accordingly, an increase in the heating surface. Moreover, this increase in the HES is ahead of the tendency to decrease the resistance with increasing distance between layers of coils.

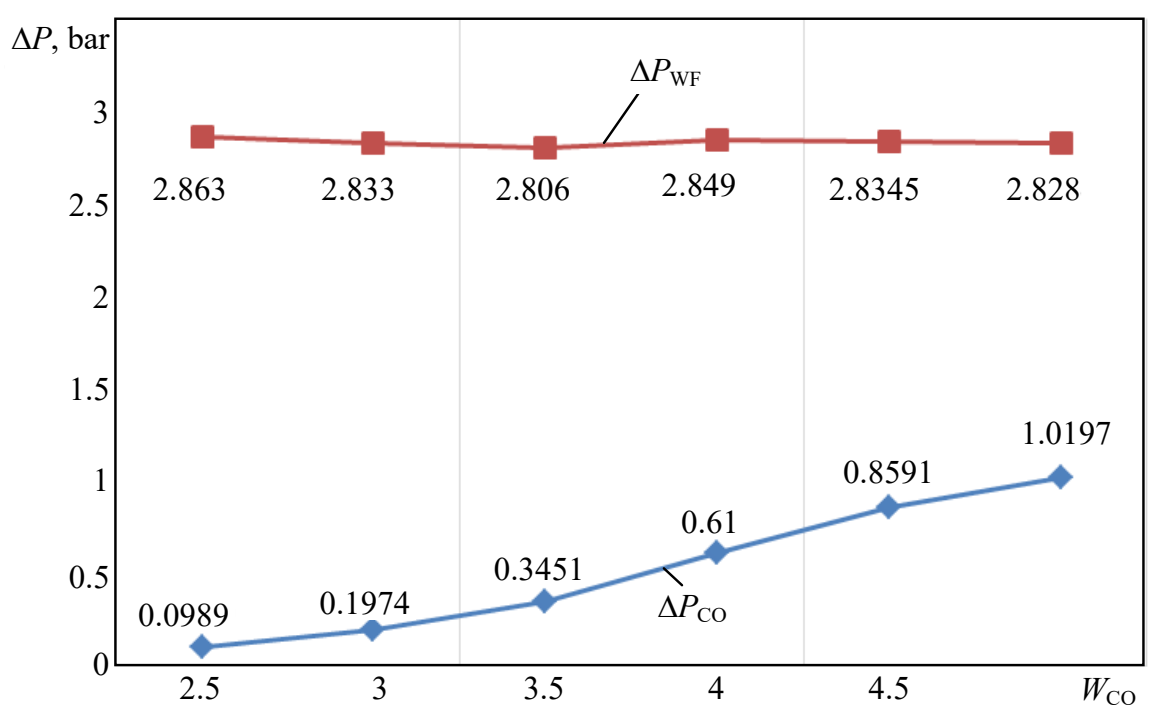

Fig. 2. Influence of changing the coolant velocity on the hydraulic resistance of HES

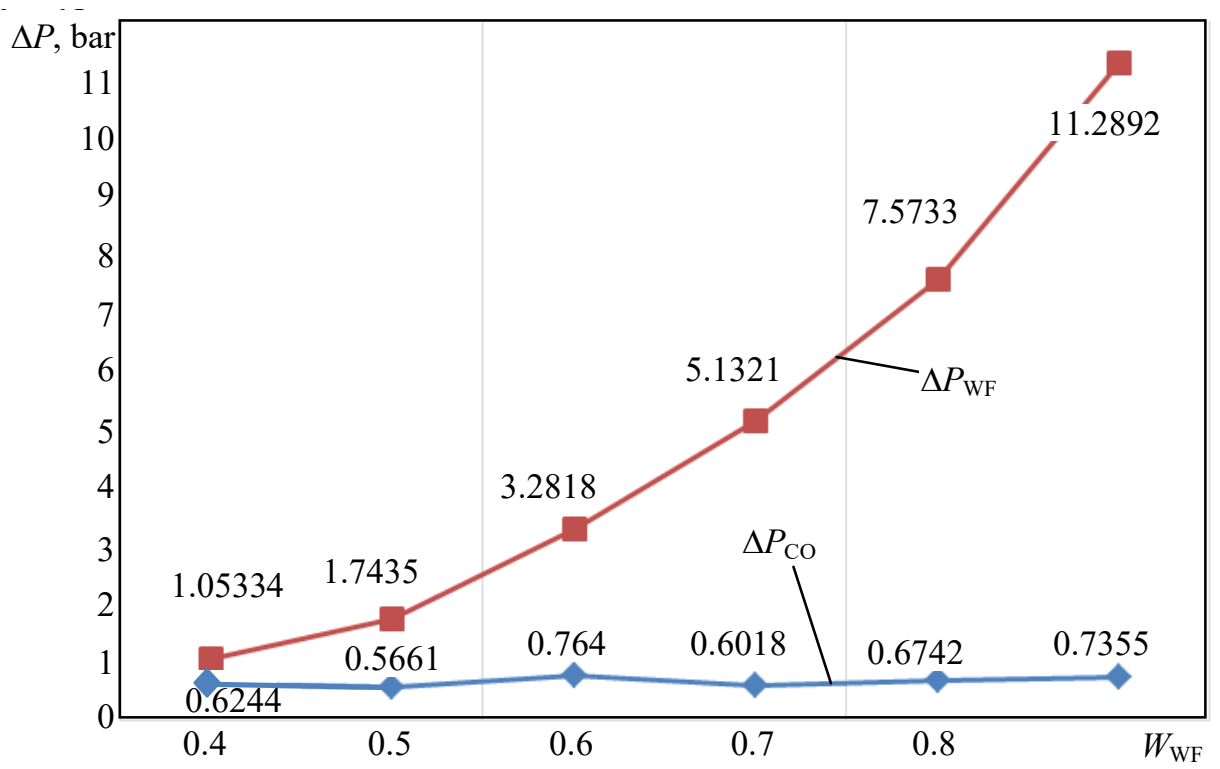

Fig. 3. Influence of the change in the feed water velocity at the inlet to the HET on the hydraulic resistance of the HES 


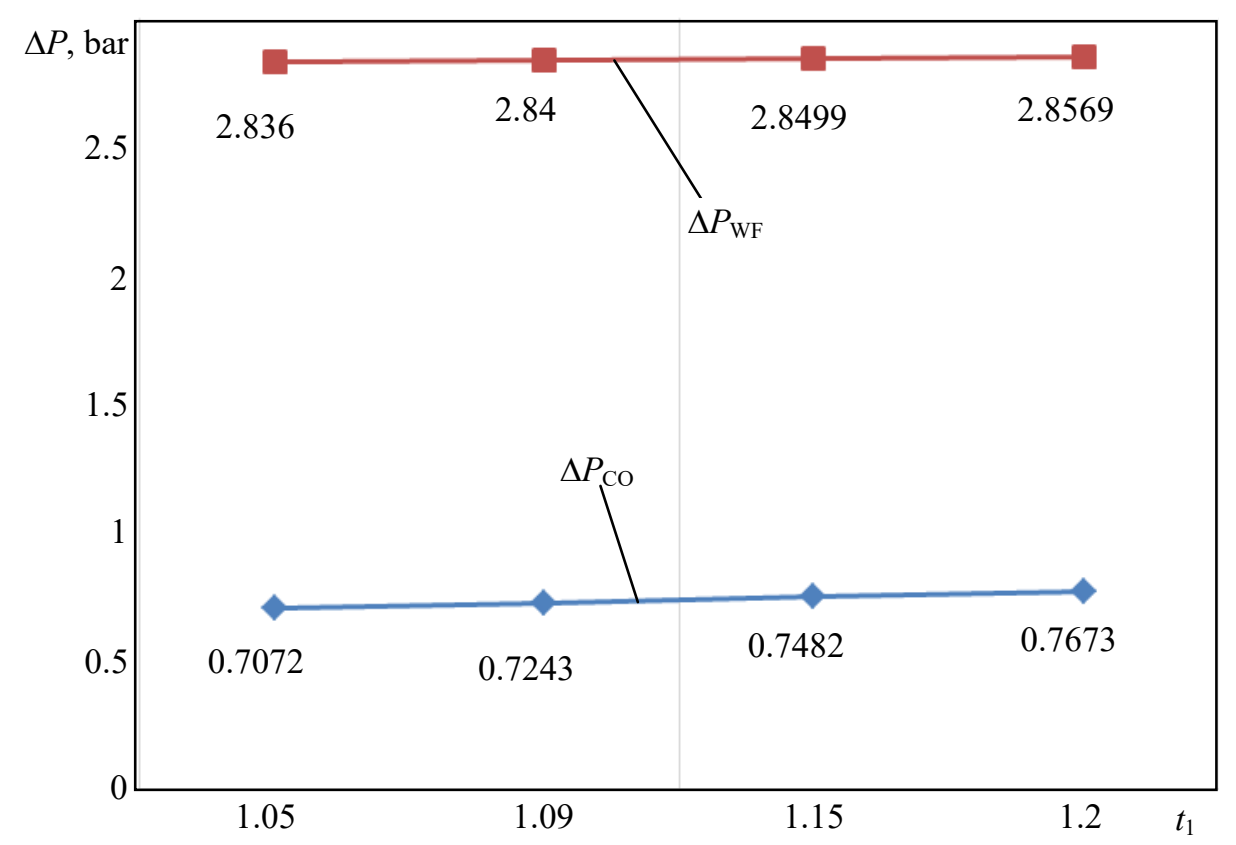

Fig. 4. The effect of changing the relative pitch between the coils along the vertical on the hydraulic resistance of the HES

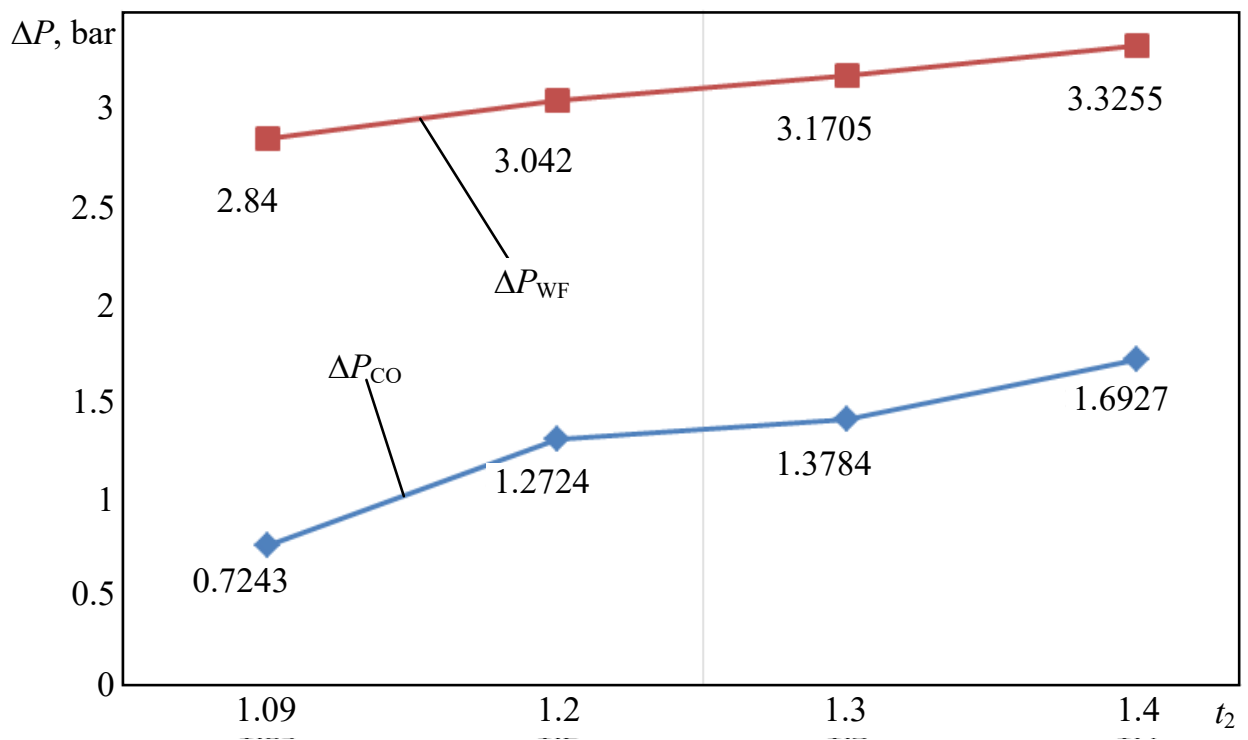

Fig. 5. The effect of changing the relative pitch between the layers of coils on the hydraulic resistance of the HES

\section{Conclusions}

5.1. A feature of calculating a straight-through steam generator with a cylindrical coil heating surface is that the number of independent design parameters is equal to five. These are the inner diameter of the tube, the vertical pitch between the coils, the horizontal pitch between the layers of the coils, the feed water velocity at the tube inlet, the coolant velocity in the annular space. Unlike other designs, an additional parameter is the coolant velocity, which determines the number of layers of coils. 
5.2. As a result of the analysis of various sources for calculating the hydraulic resistance during the movement in the tubes of a boiling working medium and the transverse washing of the coils with a coolant, formulas were chosen that give a result close to the calculation data using the ASPEN-TECH computer code.

5.3 As shown by the calculations, a change in the feed water velocity has little effect on the resistance of the coolant. In turn, the change in the speed of the coolant has little effect on the resistance of the working fluid. Increasing the pitches both between the coils (vertically) and between the cylindrical layers of the coils unexpectedly leads to a slight increase in resistance due to the deterioration of heat transfer and an increase in the heating surface. Taking these factors into account makes it possible to reduce the number of variant calculations during optimization.

5.4. The following features allow you to simplify and speed up the calculation. Acceleration resistance for economizer, evaporator and superheating sections can be omitted separately. Acceleration resistance can be calculated for the entire SG both for CO and WF.

5.5. The gravity resistance for the coolant can be calculated for the entire HES height. The gravity resistance along the working medium should be determined as the sum of the leveling resistances at each section.

5.6. Variant calculations of the influence of the main design parameters on the hydraulic resistance of a once-through SG with a coil heating surface were carried out. It was revealed that the hydraulic resistance of the OTSG changes in accordance with the direction of the change in the area of the HES. Of the three sections of heat transfer, the evaporative section has a decisive contribution to the resistance. Of the three components of the total resistance, the main contribution is made by the frictional resistance.

\section{Література}

1. Deployment Indicators for Small Modular Reactors. IAEA-TECDOC-1854. IAEA. 2018. Vienna. URL: https://www.iaea.org/search/google/IAEA-TECDOC-1854.

2. Kessides I., Kuznetsov V. Small Modular Reactors for Enhancing Energy Security in Developing Countries. Sustainability. 2012. 4(8). P. 1806-1832. DOI: https://doi.org/10.3390/su4081806.

3. Small modular reactors. IAEA. URL:https://www.iaea.org/ru/temy/malye-modulnye-reaktory.

4. Rosner R., Goldberg S., Hezir J. Small modular reactors - key to future nuclear power generation. Technical Paper-1, University of Chicago and Energy Policy Institute at Chicago (EPIC). 54 Chicago (2011). URL: https://energy.gov/sites/prod/files/2015/12/f27/ECON-SMRKeytoNuclearPower Dec2011.pdf.

5. Lee K.H., Kim M.G., Lee J.I., Lee P.S. Recent Advances in Ocean Nuclear Power Plants. Energies. 2015. 8(10), P. 11470-11492. DOI: https://doi.org/10.3390/en81011470.

6. Kuznetsov V. Options for small and medium sized reactors (SMRs) to overcome loss of economies of scale and incorporate increased proliferation resistance and energy security. Progress in Nuclear Energy. 2008. 50, 2-6. P. 242-250. DOI: https://doi.org/10.1016/j.pnucene.2007.11.006.

7. Rowinskia M.K., Whitea T.J., Zhao J. Small and medium sized reactors (SMR): A review of technology. Renewable and Sustainable Energy Reviews. 2015. 44. P. 643-656. DOI: https://doi.org/10.1016/j.rser.2015.01.006.

8. Carelli M.D., Ingersoll D.T. Handbook of Small Modular Nuclear Reactors; Elsevier Ltd.: 2015. Cambridge, UK. P. 27-60. URL: http://www.aben.com.br/Arquivos/350/350.pdf.

9. Innovative Small and Medium Sized Reactors: Design Features. Safety Approaches and R\&D Trends., Final report of a technical meeting held in Vienna, 7-11 June 2004. IAEA-TECDOC-1451. IAEA. 2005. Vienna. URL: https://www-pub.iaea.org/MTCD/Publications/PDF/TE_1451_web.pdf.

10. Introduction to Small and Medium Reactors in Developing Countries. IAEA-TECDOC-999. IAEA. 1997. Vienna. URL: https://www-pub.iaea.org/MTCD/Publications/PDF/te_999_web.pdf.

11. Advances in Small Modular Reactor Technology Developments. Printed by the IAEA in Austria. IAEA. 2020. URL: https://aris.iaea.org/Publications/SMR_Book_2020.pdf.

12. Kravchenko V.P., Zhou X.L. Methodology and results of thermal calculation of one-through steam generators for NPP of small power. Problems of Atomic Science and Technology. 2020. №2 (126). P. 8588. URL: https://vant.kipt.kharkov.ua/TABFRAME.html. 
13. Kravchenko V.P., Sereda R.M., Zhou X.L., Visotskii Y.I.., Rybakov A.H. Choice of basic construction parameters of steam generators for NPP of low power. Problems of Atomic Science and Technology. 2019. №5 (125). P. 62-68. URL: https://vant.kipt.kharkov.ua/TABFRAME.html.

14. Rassohin N.G. Steam generating units of nuclear power plants. 1987, $384 \mathrm{p}$.

15. Deev V.I., Shchukin N.V., Tcherezov A.L. Basics of calculating ship NPPs. Textbooks / Edited by prof. V.I. Deev. M. : National Research Nuclear University MEPhI, 2012. 256 p.

16. Kirillov P.L., Yuriev Y.S., Bobkov V.P. Handbook on thermohydraulic calculations (nuclear reactors, heat exchangers, steam generators). M. : Energoatomizdat, 1990. 360 p.

17. РД 24.035.05-89. Methodical instructions. Thermal and hydraulic calculation of NPP heat exchange equipment. URL: http://docs.cntd.ru/document/1200085786.

18. Mikheev M.A., Mikheeva I.M. Heat Transfer Short Course. M.-L. : Gosenergoizdat, 1960. 208 p.

19. Ship nuclear steam generating installations / D.F. Romanov, M.A. Lebedev, S.S. Savarensky et al. L. : Shipbuilding, 1967. $404 \mathrm{p}$.

20. Shamanov N.P., Peich N.N., Dyadik A.N. Ship nuclear steam generating installations: Textbook. L. : Shipbuilding, 1990. 368 p.

\section{References}

1. Deployment Indicators for Small Modular Reactors. (2018). IAEA-TECDOC-1854. IAEA. Vienna. Retrieved from: https://www.iaea.org/search/google/IAEA-TECDOC-1854.

2. Kessides, I., \& Kuznetsov, V. (2012). Small Modular Reactors for Enhancing Energy Security in Developing Countries. Sustainability, 4(8), 1806-1832. DOI: https://doi.org/10.3390/su4081806.

3. Small modular reactors. IAEA. Retrieved from: https://www.iaea.org/ru/temy/malye-modulnyereaktory.

4. Rosner, R., Goldberg, S., \& Hezir, J. (2011). Small modular reactors-key to future nuclear power generation. Technical Paper-1, University of Chicago and Energy Policy Institute at Chicago (EPIC), 54 Chicago Retrieved from: https:/energy.gov/sites/prod/files/2015/12/f27/ECONSMRKeytoNuclearPowerDec2011.pdf.

5. Lee, K.H., Kim, M.G., Lee, J.I., \& Lee, P.S. (2015). Recent Advances in Ocean Nuclear Power Plants. Energies, 8(10), 11470-11492. DOI: https://doi.org/10.3390/en81011470.

6. Kuznetsov, V. (2008). Options for small and medium sized reactors (SMRs) to overcome loss of economies of scale and incorporate increased proliferation resistance and energy security. Progress in $\mathrm{Nu}$ clear Energy, 50, 2-6, 242-250. DOI: https://doi.org/10.1016/j.pnucene.2007.11.006.

7. Rowinskia, M.K., Whitea, T.J., \& Zhao, J. (2015). Small and medium sized reactors (SMR): A review of technology. Renewable and Sustainable Energy Reviews, 44, 643-656. DOI: https://doi.org/10.1016/j.rser.2015.01.006.

8. Carelli, M.D., \& Ingersoll, D.T. (2015). Handbook of Small Modular Nuclear Reactors; Elsevier Ltd.: Cambridge, UK. 27-60. Retrieved from: http://www.aben.com.br/Arquivos/350/350.pdf.

9. Innovative Small and Medium Sized Reactors: Design Features. Safety Approaches and R\&D Trends. (2005). Final report of a technical meeting held in Vienna, 7-11 June 2004. IAEA-TECDOC-1451. IAEA. Vienna. Retrieved from: https://www-pub.iaea.org/MTCD/Publications/PDF/TE_1451_web.pdf.

10. Introduction to Small and Medium Reactors in Developing Countries. (1997). IAEA-TECD̄DC-999. IAEA. Vienna. Retrieved from: https://www-pub.iaea.org/MTCD/Publications/PDF/te_999_web.pdf.

11. Advances in Small Modular Reactor Technology Developments. (2020). Printed by the IĀEA in Austria. IAEA. Retrieved from: https://aris.iaea.org/Publications/SMR_Book_2020.pdf.

12. Kravchenko, V.P., \& Zhou, X.L. (2020). Methodology and results of thermal calculation of one-through steam generators for NPP of small power. Problems of Atomic Science and Technology, 2 (126), 85-88. Retrieved from: https://vant.kipt.kharkov.ua/TABFRAME.html.

13. Kravchenko, V.P., Sereda, R.M., Zhou, X.L., Visotskii, Y.I., \& Rybakov, A.H. (2019). Choice of basic construction parameters of steam generators for NPP of low power. Problems of Atomic Science and Technology, 5 (125), 62-68. Retrieved from: https://vant.kipt.kharkov.ua/TABFRAME.html.

14. Rassohin, N.G. (1987). Steam generating units of nuclear power plants.

15. Deev, V.I., Shchukin, N.V., \& Tcherezov, A.L. (2012). Basics of calculating ship NPPs. Textbooks / Ed. V.I. Deev. M.: National Research Nuclear University MEPhI.

16. Kirillov, P.L., Yuriev, Y.S., \& Bobkov, V.P. (1990). Handbook on thermohydraulic calculations (nuclear reactors, heat exchangers, steam generators). M.: Energoatomizdat.

17. РД 24.035.05-89. Methodical instructions. Thermal and hydraulic calculation of NPP heat exchange equipment. Retrieved from: http://docs.cntd.ru/document/1200085786. 
18. Mikheev, M.A., \& Mikheeva, I.M. (1960). Heat Transfer Short Course. M.-L.: Gosenergoizdat.

19. Romanov, D.F., Lebedev, M.A., \& Savarensky, S.S. et al. (1967). Ship nuclear steam generating installations. L.: Shipbuilding.

20. Shamanov, N.P., Peich, N.N., \& Dyadik, A.N. (1990). Ship nuclear steam generating installations: Textbook. L.: Shipbuilding.

Кравченко Володимир Петрович; KravchenkoVolodymyr, ORCID: http:// orcid.org/0000-0002-7557-3327

Сяолун Чжоу; Xiaolong Zhou

Received April 07, 2021

Accepted May 30, 2021 